\title{
Legal Framework of Shari'ah Corporations in Malaysia: Special Reference to Waqf Corporation
}

\author{
Zuhairah Arif Abd Ghadas, Hartinie binti Abd Aziz \\ University of Sultan Zainal Abidin, Terengganu, Malaysia
}

\begin{abstract}
In Malaysia, the Islamic commercial institutions were established under respective legislations which contain express term on their status as a body corporate. Examples of these institutions are Islamic banks, zakah institutions, Pilgrimage Board and Islamic insurance (takaful) companies. In 1998, Johor Corporation (JCorp) initiated a corporate waqf entity known as Waqaf An-Nur Corporation Berhad (WANCorp). In 2011, Majlis Agama Islam Wilayah Persekutuan (MAIWP) collaborated with Tabung Haji to develop a Class AWaqf building leased to Bank Islam Malaysia Berhad (BIMB). The developments in waqf involving corporate entities are worth to be analyzed in order to create a new framework of waqf practice. This paper deliberated the attributes of corporations under the Malaysian law and compares them with the principles of Islamic law (Shari'ah). For the purpose of discussion, this paper refers to WANCorp and Awqaf Holdings as examples of waqf corporations in Malaysia.
\end{abstract}

Keywords: body corporate, waqf corporation, company

\section{Introduction}

In Malaysia, Islamic institutions were established under respective legislations which contain express term on their status as a body corporate. Examples of these institutions are zakah institutions, Pilgrimage Board (Lembaga Tabung Haji) and Takaful Malaysia (an Islamic insurance company). All companies which run Shari'ah compliance businesses in Malaysia are required to be registered under the Companies Act 1965 which then entails them the status and attributes of a body corporate. The legal effect as a body corporate is it shall be an entity separated from its director or founder. Besides, it shall have perpetual succession and have the power to sue and be sued in such corporate name. As a corporation it may acquire, purchase, take, hold, and enjoy movable and immovable property, and may convey, assign, surrender, yield up, charge, mortgage, demise, reassign, transfer, or otherwise dispose of, or deal with, any of those property or any interest therein (Hassan, Abd Ghadas, \& Abdul Rahman, 2012). The doctrine of separate legal entity had been introduced by the English common law through the decision made by the court in the case Salomon v. Salomon \& Co. Ltd. (1897) where the court held that despite Mr. Salomon having the control over the company, it was neither his agent nor trustee (Zuryati, Azrae, \& Yusoff, 2009).

Thus, it appears that there are two types of person recognized by the law. The first one being the natural person or human beings; and the second would be the artificial person (Tan Lai v. Mohamed Bin Mahmud

\footnotetext{
Zuhairah Arif Abd Ghadas, Dean, Faculty of Law and International Affairs, University of Sultan Zainal Abidin. Email: zuhairahariff@unisza.edu.my.

Hartinie binti Abd Aziz, Ph.D. candidate, Faculty of Law and International Affairs, University of Sultan Zainal Abidin.
} 
[1982]), which includes any being other than human being which the law recognized as having duties and rights. One of the most recognized artificial people is the corporation. Thus, according to Aiman (2002; as cited in Zuryati et al., 2009), the doctrine of separate legal entity is a fundamental legal principle which draws a distinction between an incorporated company and those people who have a control over it. A company will continue unchanged even if the identity of the participants in it changes.

This paper will compare the attributes of corporations under the Malaysian and Shariah law. For the purpose of discussion, this paper refers to WANCorp and Awqaf Holdings as examples of waqf corporations in Malaysia.

\section{Waqaf Corporation}

Waqf is an Islamic concept of endowment whereby the properties are held in trust and used for a charitable or religious purpose. In Waqf Corporation, the practice of Waqf (endowment) is structured into the commercial corporations whereby it is compulsory for the companies to contribute to the society and it is a must for them to spend certain amount of their profit to the community. Under this new "corporate practice", the companies are reminded not to forget the values of Islamic teachings in carrying on business which includes the obligation to donate a certain proportion of profit to the community or for charitable causes.

According to Tan Sri Ali Hashim in his books, Strategi Jihad Bisnes, Waqf Corporation is a new corporate institution initiated by Malaysia without any other model alike in Islamic world. Thus, to define what waqf corporate is, a special resolution is needed to identify the criteria that need to be fulfilled as a waqf corporate. Nowadays, there are a lot of institutions doing waqf in share of ownership in company for the purpose of public interest in the society as what had been done by Vehbi Koc Foundation in Turkey.

The first waqf corporation in Malaysia is Waqaf An-Nur Corporation (WANCorp) which had been established in 2004 by Johor Corporation (JCorp). Waqaf An-Nur Corporation is a company limited by guarantee established by JCorp of Malaysia. Initially registered in 2000 as Pengurusan Klinik Waqaf An Nur Sdn Bhd offering medical services at a charge of RM5 per treatment to low-income patients at clinics located largely at mosque compounds financed by waqf funds, the company was elevated into a Waqf Corporate entity in 2006 when JCorp endowed into waqf US\$66 million or RM200 million at net asset value of JCorp shares in three Malaysian pubic listed companies (PLCs). The shares involved were in a palm oil plantation company Kulim Malaysia Bhd, a top Malaysian company involved in a private healthcare delivery, KPJ Healthcare Bhd, and a leading property developer, Johor Land Bhd. However, Johor Land Bhd shares were subsequently replaced through istibdal by Al-Aqar KPJ REIT Bhd, a healthcare-related Islamic property trust copay that is also listed on the Malaysian Bourse.

Based on the experience of WANCorp, there are eight criteria that need to be fulfilled to qualify the corporation as a waqf corporation:

(1) The corporation must be established under the Companies Act 1965 as a company limited by guarantee;

(2) As a corporate waqf, the company must be empowered to receive endowments in the form of cash, share, business, physical or intangible assets including land, buildings or intellectual property from institutions, corporations or members of the public, though ownership of physical assets is in themselves not necessarily to be registered as waqf assets;

(3) The corporate waqf must have been appointed as a nazir or mutawalli by Islamic religious authority (in the Malaysian case - by one of Malaysia's Majlis Agama Islam at the state and national levels); 
(4) The company must at all times uphold and abide by business principles and best corporate practices, undertaking business ventures through sustainable entrepreneurial effort. The key to corporate waqf success therefore depends on its ability to mobilise the best entrepreneurial talent to grow business over the long term and create business opportunities for aspiring entrepreneurs;

(5) To achieve the long-term goal of economically empowering the ummah, corporate waqf had given higher priority to accumulating and conserving the resources by stipulating in the trust deed that $70 \%$ of annual profit/surplus be allocated for reinvestment and not more than $30 \%$ to be distributed for charity;

(6) The waqf corporate has full autonomy in the business transaction led by the CEO with the supervision of board of director;

(7) The waqf corporate will open the membership to public by waqf fee based on category as determined in the memorandum of association of company;

(8) The waqf corporation has to practice the good corporate governance to determine the accountability of the company. It must at all times be fully consistent with the Shariah, and aspire to realise the goals of Maqasid al-Shariah. ${ }^{1}$

Based on the eighth criteria mentioned above, we can see the difference of waqf corporate and waqf saham which had been practiced by many companies. The waqf saham practiced before is more on fulfilling the corporate social responsibility and the company will be totally depending on the waqf fund given by the public while in the waqf corporate, it was aimed to generate the fund for business long term and to make sure that the waqf fund given by the waqif will create the wealth for the benefit of Muslim society.

Another example of waqf corporation in Malaysia is Awqaf Holding Bhd (AWQAF) which was established by Malaysian Islamic Chamber of Commerce in 2010. AWQAF is a company limited by guarantee and adopted all the basic parameters of WANCorp as corporate waqaf with one exception, that is, its initial funding is financed not by Government-linked Company (GLC) but by its founding members and through public funding participation. One unique feature of AWQAF is that, it integrates into its business model the opportunity for business investments as well as contributing to a waqf for a return in the hereafter (Hashim, 2015).

\section{Observation}

It can be concluded that in Malaysia, all companies need to be registered under the Companies Act 1965 for which it was based on conventional framework. And even though the application of the common-law doctrine of corporate legal personality as an artificial person could be accepted under Shari'ah, it is subject to certain modifications and therefore shall not be a direct application. Being one of Shariah compliance business entities, it is important for waqf corporation to embrace the framework for Shariah corporation.

\section{Legal Entity of Body Corporate Under Shariah}

As mentioned earlier, under the conventional corporate structure, a company is recognised as a body corporate created by law to be an artificial person which holds few attributes inter alia right to sue and being sued and power to hold a property under its own name. However, under shariah law, the discussion on artificial person is derived from the views of the Muslim Jurists on the entity of shaksiyah i’itibariyah (الاعتباريةالثخصية). According to a modern Muslim scholar, Imran Ahsan Khan Nyazee, there has been a prolonged debate among

${ }^{1}$ Retrieved from http://awqaf.com.my/pengenalan/ciri-ciri-waqaf-korporat/. 
Islamic jurists on the existence of the concept of a fictitious person (shaksiyah i'itibariyah) and the majority of the modern scholars insist that such concept was known to Islamic law while some are doubtful whether Islamic law was aware of such concept (Nyazee, 2006). Nyazee also contended that although Shariah does recognize the principle artificial person, it does not mean that all institutions based on this concept automatically become legal. Under Shari'ah, the implementation of such concept in different forms needs separate analysis. As an example, the existing structure of the business corporation which enables it to issue securities must be free from riba and it must also fulfill all the requirements on conducting businesses in Islam.

Mustafa (Al-Zurqa, 1964) took the view that the theory which recognizes the entity other than human being as a legal person can be justified through the theory of fiqh known as al-Dhimmah. The term of al-Dhimmah has been discussed by many Muslim jurists in various opinions. According to Madhab al-Syafie jurists, al-Dhimmah is an attribute of human being with duties (al-ilzam) and also obligations (al-iltizam) (Al-Kabashi, 1989). This definition is also accepted by jurists of Madhab Maliki, Hanafi and Hanbali (Al-Buhuti, 1947).

Al-Sarakhsi defined al-Dhimmah as a fixed attribute of a person accepting obligations and duties. This concept relates to an obligation and capacity (al-ahliyyah) as well. The application of this concept as discussed and applied by the jurists since the early era of the development of fiqh does not connote the same definition. The majority of the fuqaha have acknowledged the existence of other than human being which is entitled to some rights and responsibilities. However, unlike the common law, the Islamic scholars discussion concerning the artificial person not only relies on the entity itself but more on whether it is subject to obligation and responsibilities as required under Islamic law.

According to al Makashifi Thoha al-Kabashi (Al-Kabashi, 1989), the fiqh of Islam does recognize the existence of an artificial person (al-syakhsiyah al-I'tibariyyah) as it is applicable to hospitals, waqf, and syarikaat and as al-Dhimmah, these entities have certain rights and obligations. He also claimed that this artificial person enjoys the concept of al-ahliyyah al-kamilah similar to human being with certain rights and obligations as stated under Section 53 of the Egypt Civil Law that artificial person enjoys full rights unless such rights are restricted only to human being. Although there are many Muslim jurists who supported the application of doctrine of artificial person in Shari'ah, there are also some Muslim scholars who contested the acceptance of such principle in Shari'ah. For example, al-Bazdawi and al-Nawawi took the view that al-Dhimmah is a dzat which is real and cannot be fictitious because the Syariah only imposed obligations and rights on real person. Al-Tahanawi also emphasized that the term al-Dhimmah is synonymous to human's attribute and not applicable to artificial entity as it has relevancy to interpretation of liability and obligation. Al-Sarakhsi highlighted in his book that when dhimmah was offered to the mountains, they refused it as they would be afraid that they cannot fulfill the required obligations but human being accepted it. Thus, al-Dhimmah is an attribute conferred only by Allah swt and it is a trust resulting from a covenant ('ahd). The fact that dhimmah is a covenant between Allah swt and the 'abd (servant of Allah) means that it can only be assigned to a natural person (Nyazee, 2003). As such, unlike the common law, the status of legal person in Islam cannot be conferred to entities other than human. Abdul Aziz Ahmad al-Bukhari (al-Bazdawi) took the same view as Al-Sarakhsi and emphasized that dhimmah refers to 'ahd (covenant) as Allah created a mankind with amanah, aql, dhimmah, enjoys the right of innocence ('usmah), freedom and ownership and carries the duties as Allah's rights towards him (Al-Bukhari, n.d.). 
Referring to the modern Muslim jurists, the theories of artificial legal person and corporate personality are generally viable but such acceptance cannot be absolute or total adoption of the common law doctrine. A balance approach is highlighted by Nyazee (2006), whereby he contended that the ruler may assign a restricted or limited dhimmah to a non-human on the following conditions:

Firstly, no religious duties will be expected of a fictitious person. In other words, the fictitious person will not be subject to the khitab of ibadat and will not be liable for any religious duty or obligation that may flow from it. Thus, it will have no liability for zakat, for sadaqah, or for any other religious tasks as these duties are attached to the 'ahd of human with the creator (Allah swt).

Secondly, some form of 'aql must be associated with the fictitious person. This 'aql may be that of one individual or group of individuals like the board of directors. The ahliyyat al-ada' will always be associated with this source of ' $a q l$, and so will the liability for such acts.

Thirdly, a concept of dual title of ownership must be associated with a fictitious person. Any property held by the fictitious person in its own name must be assumed to be held on behalf of the members of this fictitious person as a result of khalt or mingling of capitals. In addition, the body corporate may have full right of disposal and transaction in the property if so permitted by its members. Referring to the guidelines proposed by Nyazee, it is obvious that in adopting the common law doctrine of corporate personality, there should be some modifications to the obligations of the company as a legal entity and to the board of directors and members who form the "aql" of the companies. Rather than having total independent and separate legal entity from the directors and members, Nyazee highlighted that in Shari'ah corporations, there should be a dual ownership and liability structure. This is important because as an artificial person, the company could not in reality own and manage properties and also cannot be physically arrested and make accountable for default with the third parties. In short, although the adoption of the common law doctrine of artificial person is possible under Shari'ah, the application of the law under Shariah requires certain modifications.

\section{Legal Framework for Shariah Corporation}

In Malaysia, all Islamic commercial institutions were registered under the Malaysian Companies Act 1965. These institutions include tabung haji, zakah, and waqf corporation. As a creature of the statute, the existence of a company is totally dependent on the provisions of the Companies Act. Thus, it is recommended that all Islamic commercial institutions such as waqf corporation be framed under Shariah corporate structure.

Shariah corporate structure is not similar with the conventional structure. The legal framework for the Shariah corporation should fulfill all the requirements below.

\section{Maqasid Syariah as the Basis of the Business Framework}

The term Maqasid is derived from a verb qaseda which means the goals and purposes. Maqasid itself means goals or objectives and when such term is attached to the word Shari'ah, it specifically refers to goals or objectives of Shari'ah. According to Imam al-Ghazali, the objective of the Shari'ah is to promote the well-being of all mankind, which lies in safeguarding their faith (din), their human self (nafs), their intellect ('aql), their lineage (nasl), and their wealth (mal) (Chapra, n.d.).

The goal of sacrifice or good deeds according to Allah (S.W.T) is the sincerity and Taqwah (piety). In other words, it can be said that all business activities should be carried out based on sincerity and piety. However, as is seen in the above verse, all undertakings must be done to please Allah (S.W.T), which is the 
common requirement for any good deed in Islam. Therefore, corporations and all business entities in an Islamic state should render their business activities only for the sake of the God. The Prophet Muhammad (S.A.W) highlights the importance of giving rather than taking and everyone should do charity especially when one is self-sufficient.

\section{Shariah Good Governance}

Corporate governance is the relationship among various participants (CEO, management, shareholders, and employee) in determining the direction and performance of corporations. It ensures that the board of directors is accountable for the pursuit of corporate objectives and that the corporation itself conforms to the law and regulations (Choudhury \& Hoque, 2006). Generally, it is observed that the main objective of the corporation including the so-called Islamic corporation is to maximize the shareholder's value of wealth. This governance structure in Islam does differ from the normal corporate governance in the standardization of rules which must obey the Shariah rules stated in the holy Quran (Alnasser \& Muhammed, 2012).

\section{Shura}

Shuratic decision-making procedures provide a vehicle for ensuring that corporate activities and strategies are fully discussed and that a consensus-seeking consultative process is applied. Directors and senior managers would be expected to listen to the opinions of other executives before making a decision and shura members would include, as far as possible, representatives of shareholders, employees, suppliers, customers, and other interested parties (Lewis, 2005).

\section{Hisba}

The institution of hisba offers a framework of social ethics, relevant to monitor the corporation, with the objective of encouraging the correct ethical behaviour in the wider social context. It also empowers individual Muslims to act as "private prosecutors" in the cause of better governance by giving them a platform for social action. It provides a device to solicit juristic advice, monitor compliance with Islamic precepts, and collect zakah. This extra layer of auditing and accountability for resource use ensures that the enterprise operates as an Islamic concern (Lewis, 2005).

\section{Conclusion}

Being a business entity which embraced Shariah principles, it is important for waqf corporation to adhere to a legal framework which complies with the Shariah principles. The above legal framework is highly proposed for all waqf corporations. It is also proposed for the Companies Act to be reviewed to identify provisions which are not in compliance with Shariah principles.

\section{References}

Al-Buhuti. (1947). Kashshaf al-qina (Vol. 3). Cairo.

Al-Bukhari, A. A. (n.d.). Kashful Asrar an usul Fakhri al-Islam.

Al-Kabashi, A. M. T. (1989). Al-Zimmah wa al-Haq wa al-Iltizam wa Ta'thiruha bi al-Mawt fi al-Fiqh al-Islami. Dirasah muqaranah. Riyadh: Maktabah al-Haramayn.

Alnasser, S. A. S., \& Muhammed, J. (2012). Introduction to corporate governance from Islamic perspective. Humanomics, 28(3), 220-231. doi: 10.1108/08288661211258110

Al-Zurqa, M. A. (1964). Al-Madkhal ila Nazariyyat Al-Iltizam Al-Ammah Fi Al-Fiqh Al-Islami.

Chapra, M. U. (n.d.). The future of economics: An Islamic perspective. Leicester: The Islamic Foundation. 
Choudhury, M. A., \& Hoque, M. Z. (2006). Corporate governance in Islamic perspective. Corporate Governance: The International Journal of Business in Society, 6(2), 116-128. doi: 10.1108/14720700610655132

Hashim, M. A. (2015). Strategi Jihad Bisnes. TelagaBiru.

Hassan, H., Abd Ghadas, Z. A., \& Abdul Rahman, N. (2012). The myth of corporate personality: A comparative legal analysis of the doctrine of corporate personality of Malaysian and Islamic laws. Australian Journal of Basic and Applied Sciences, 6(11), 191-198.

Lewis, M. K. (2005). Islamic corporate governance. Review of Islamic Economics, 9(1), 5-29.

Nyazee, I. A. K. (2003). Islamic jurisprudence. IIT, Petaling Jaya: The Other Press.

Nyazee, I. A. K. (2006). Islamic law of business organization. Kuala Lumpur: The Other Press.

Zuryati, Z. A., Azrae, A. N., \& Yusoff, M. (2009). Separate legal entity under Syariah law and its application on Islamic banking in Malaysia: A note. The International Journal of Banking and Finance, 6(2), 139-154. 